\title{
Environmental Impacts-Coastal Erosion and Coastline Changes
}

Tomasz A. Łabuz

\begin{abstract}
Climate change is having an undeniable influence on coastal areas. This chapter describes the growing threat of climate change on the Baltic Sea coastline, with an emphasis on field research focused on storm surges and coastal retreat. The main climatic factors driving change in the Baltic Sea coastal zone are wind, waves, storm surges, ice jams and flooding. The cumulative effects of these drivers are also important. For example, a costly coastal protection scheme in one area may result in coastal erosion in another. Natural and man-made coastal features are experiencing unprecedented change; important natural habitats, coastal settlements and local economies are all being affected. The extent of storm surge impacts depends on the exposure of a shoreline to a surge event. The submergent and soft coastal relief of the southern Baltic Sea area is under most threat; the rate of retreat depending on the frequency and strength of the storm surges. The rate of coastal retreat has also increased in recent years due to sealevel rise and loss of beaches.
\end{abstract}

\section{Keywords}

Coast erosion - Threats for coast - Coast type response for climate change

\section{$20.1 \quad$ Introduction}

The coastal zone is one of the most dynamic environments in the world, because it is where different geospheres interact. Taking place over a range of timescales, these interactions cause dynamic coastal rebuilding, referred to coastal morphodynamics. The factors responsible for change in the coastal zone may be grouped into geological and geomorphological, hydrodynamic, biological, climatic and anthropogenic factors. The main geological factors-sediment type, arrangement and resistance of sediment structures, and isostasy - are the basis of the morphological processes and the development of coastal relief. Geomorphological processes are influenced by many external forces, including climatic factors such as precipitation rain and wind. They are

T.A. Łabuz ( $\square)$

Institute of Marine and Coastal Sciences, Szczecin University, Szczecin, Poland

e-mail: labuztom@univ.szczecin.pl responsible for the development of typical relief forms and sediment supply. Biological factors mainly concern the influence of plants and are responsible for the development of particular coastal types. Anthropogenic factors refer to many human activities taking place within the coastal zone: settlements, industrial development, agriculture, deforestation and coastal protection. The coastal system is a dynamic complex of sensitive factors and typically responds in a nonlinear morphological manner (Dronkers 2005). The wide range of natural and human influences on the Baltic Sea coastline makes it difficult to identify the specific effects of climate change. Exposure to wind is a key factor for coastal development. Climatic conditions greatly influence the inflow of material to the coastal zone, by determining the amount and origin of terrigenic material supplied to the coastal zone as well as the amount of biogenic material produced and supplied to the sediments.

The combination of sea-level rise, land subsidence and isostatic rebound creates both emergent and submergent coasts. Emergent coasts are identifiable by accumulative 
landforms or ancient coastlines recorded in the relief or sediment structures on land. Submergent coasts occur where rising sea level and subsidence cause coastal retreat, and where water is entering and eroding land features. Crest movements show the 'sinking' of the southern Baltic Sea coast and uplift in Scandinavia. For instance, glacial isostatic adjustment (GIA) has caused the coastal zone in Estonia to emerge throughout the Holocene (last 10,000 years), with current uplift rates of 1.0-2.8 $\mathrm{mm}^{-y_{e}{ }^{-1}}$ and with maximum uplift located on the north-western coast (Vallner et al. 1988; Ekman and Mäkinen 1996). Transgression is expected with the sinking of the coast (Harff and Meyer 2007) (for more information on land movements due to GIA see Chap. 9).

The main coastal features in the Baltic Sea region are sand or gravel spits with diversified dunes, cliffs cut in a variety of sediments and low-lying areas such as lagoons, wetlands and salt marshes (Fig. 20.1). Accumulative features such as sand spits or beaches are formed by currents and waves. Dunes developed on sandy spits are higher origin forms accumulated in the past or now. They are developed as aeolian forms shaped by wind. Cliffs may be cut into hard rock or into soft clays, tills and sands and are usually higherorder relief forms shaped by erosion processes such as waves or landslides.

Different types of Baltic Sea coast may be distinguished based on the strength of the factors affecting the various geological structures of the coastal zone. Most Baltic Sea coastlines and coast types were formed during the last deglaciation and the subsequent Holocene sea transgression. Unconsolidated glacial sediments were shaped into moraine hills separated by low-lying fluvioglacial valleys. High, soft moraine hills attacked by waves were shaped into relatively steep cliffs. Sea transgression flooded low-lying areas, creating shallow bays, lagoons and swampy areas. In such areas, sediment accumulation by long-shore currents often created emerging barriers. The southern Baltic Sea coast is mainly composed of moraine cliffs (made by glacial tills, clays and fluvioglacial sands) and sandy or gravel coasts developed as spits. Abundant sand sediment has led to the creation of various sandspits, with the longest occurring on the southern Baltic Sea coast, such as the Vistula and $\mathrm{Cu}$ ronian sandspits. Lagoons, shallow sea bays and coastal lakes were formed on low-lying coast, where organic accumulation and sedimentation dominated. Spits such as islands or barriers develop where sediment, moving alongshore, is deposited at the mouth of estuaries and other places with an abrupt change in the direction of the coast (Trenhaile 1997). Several sandy barrier islands occur on the German Baltic Sea coast (e.g. Hiddensee), others built by gravel or pebbles, in Estonia.

Owing to long-shore transport and the origin of land features, the Polish, Lithuanian and Latvian coastlines are effectively aligned, with sandy barriers separating valleys, deltas, lakes and lagoons from the open sea. The German and Danish soft coasts are more circuitous, due to numerous bays, peninsulas and islands.

The northern part of the Baltic Sea coast is mainly formed by isostatic uplift due to the loss of glacial cover in Scandinavia. In some places, accumulative forms occur in bays or river deltas. Finland and Sweden have emergent coasts where abundant skerries form archipelagos. Some U-shaped fjords were formed by glaciers in rocky, mainly igneous beds (Fig. 20.2b) with the presence of some sandy, accumulative barriers or beaches. Rocky limestone or chalk beds, found in Estonia and on the Baltic Sea islands, have formed cliff coasts (Fig. 20.2e, f).
Fig. 20.1 Features and zones of the main Baltic Sea coast types. a Soft cliff coast, b Sandy coast with foredunes, $\mathbf{c}$ Rocky coast
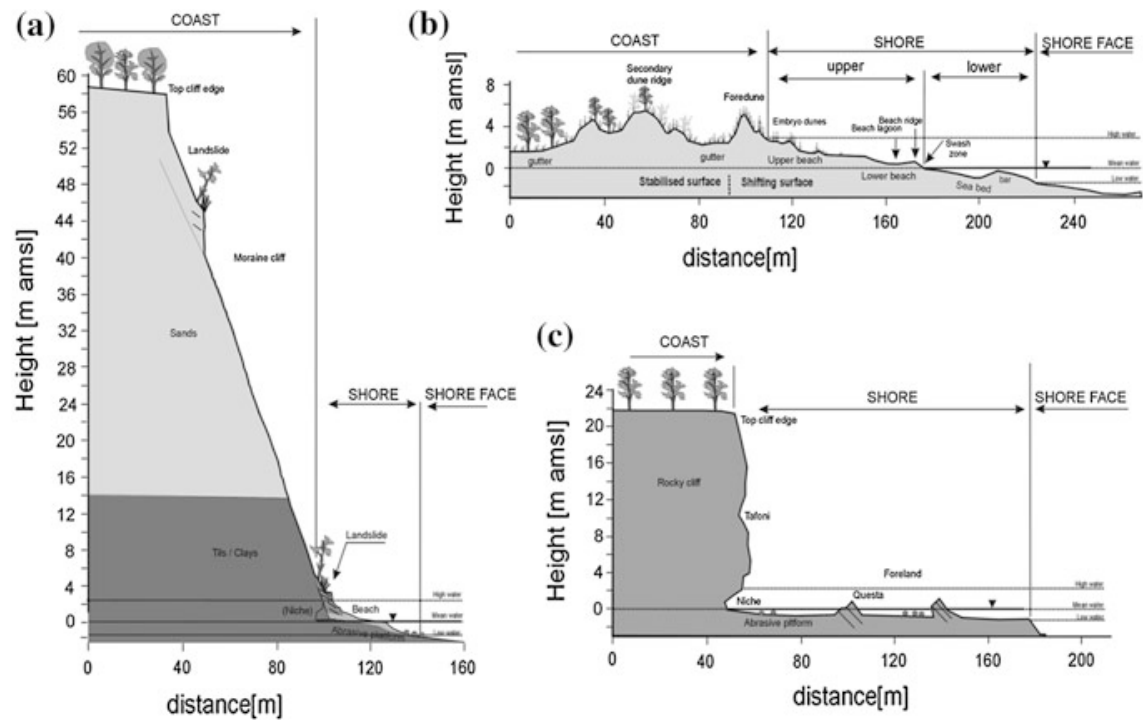

(c)

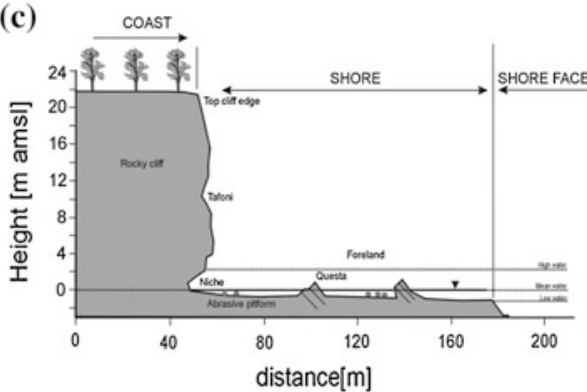


(a)
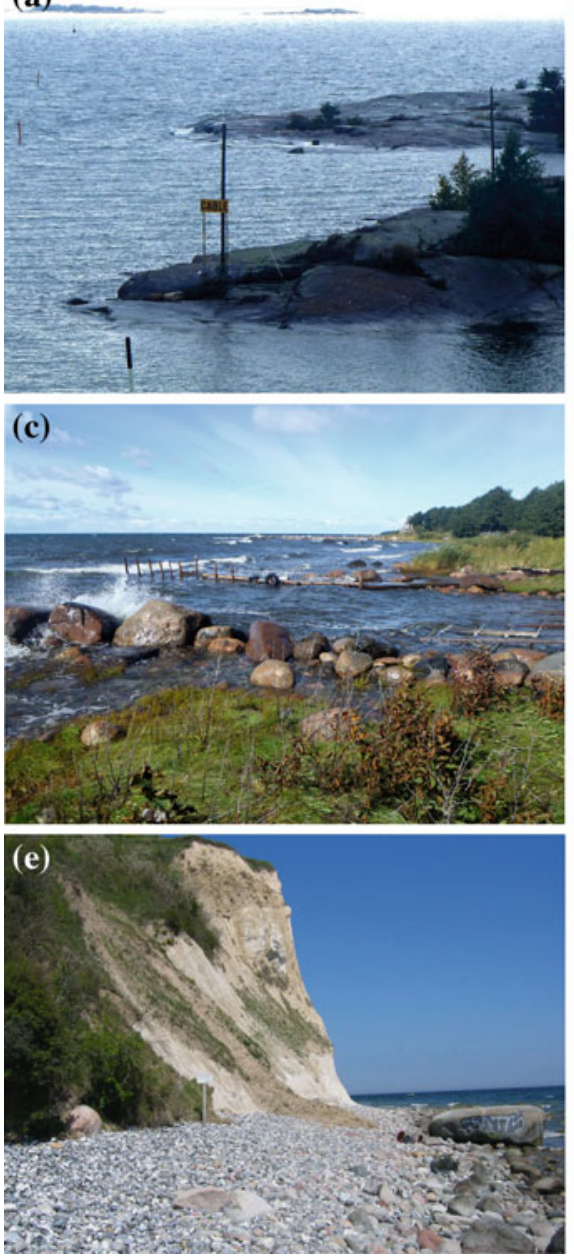

Fig. 20.2 Coastal types of the Baltic Sea. a Skerries in the Gulf of Finland, Finland; b Igneous rock, low coast shaped by glaciers, Helsinki, Finland; c Low coast of glacier boulders, northern Estonia; d Wetlands in southern Sweden near Malmö; e Rocky, chalk cliff covered by moraine sediments with an abrasive platform instead of beach, Rügen Island, Germany; f High-eroded cliff-klint coast in Estonia; $\mathbf{g}$ High soft moraine cliff coast of tills and fluvioglacial sands, Wolin Island, Poland; $\mathbf{h}$ Typical cliff coast of tills and clays of moraine

\subsection{Characteristics of Coastal Types Around the Baltic Sea}

The Scandinavian coast is mainly covered by hard rock, such as igneous, sandstone or limestone forms. It has been shaped by glaciers that have formed U-shaped fjords or flat coastal forelands. In the Bothnia Gulf, there is a skerry-type coast, which due to uplift is formed by many small islands. Skerries are commonly formed by rocky blocks that emerge from the water, separated by ice-shaped channels. The bedrock geology of the south-west archipelago consists of fractured and faulted Precambrian granites and schists of the Fennoscandian Shield that comprise the peneplain surface
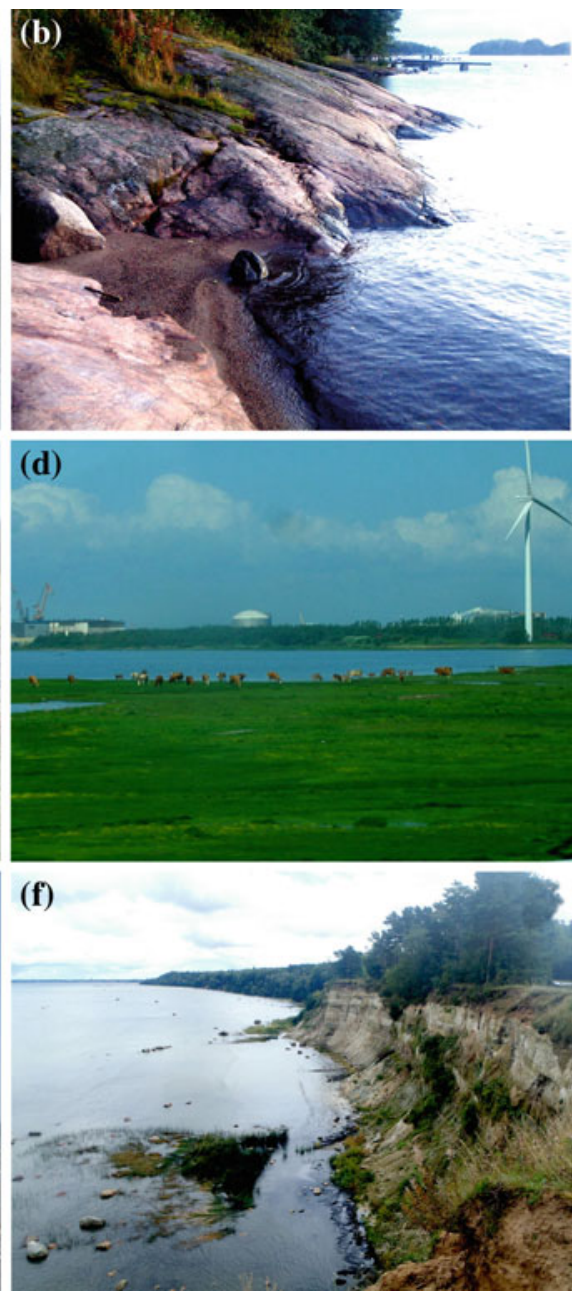

deposits, landslides on the beach caused by ongoing storm surge, Sambian Peninsula, Kaliningrad region, Russia; i Low eroded coast without dune ridges in Heiligendamm, Germany; $\mathbf{j}$ Low coast of end moraine deposits covered by sands, Latvia; k Retreating dune coast entered and covered peatbog, Kolobrzeg, middle Polish coast; I Sandspit dunes: shifting inland with typical accumulative foredunes, Lebsko Lake Sandbar, Poland (Photos T.A. Labuz)

that slopes gently south-west (Schwartz et al. 1989). The following sections describe the coastal types by country. See Figs. 20.1 and 20.2 for the main the coastal types occurring in the Baltic Sea region.

\subsubsection{Finland}

Small patches of dune landscape are widespread on the Finnish coast, formed mainly from skerries (Fig. 20.2a) and post-glacial beaches on rapidly rising coastlines (Hellemaa and Doody 1991). The uplift rate is up to $9 \mathrm{~mm}_{\text {year }}{ }^{-1}$, particularly in the Gulf of Bothnia. The dune landscape consists of parallel ridges separated by low, wet depressions arranged 

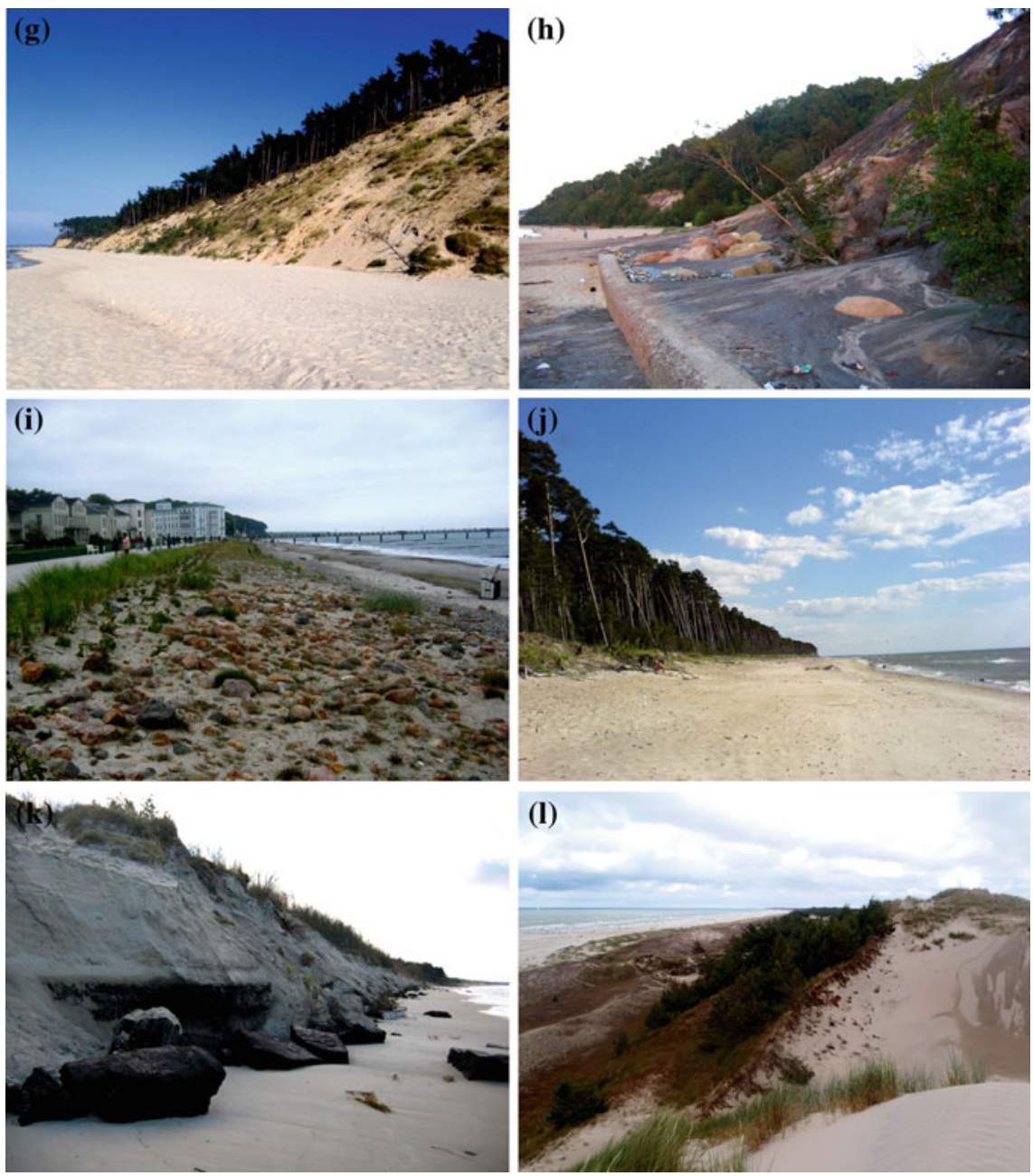

(l)

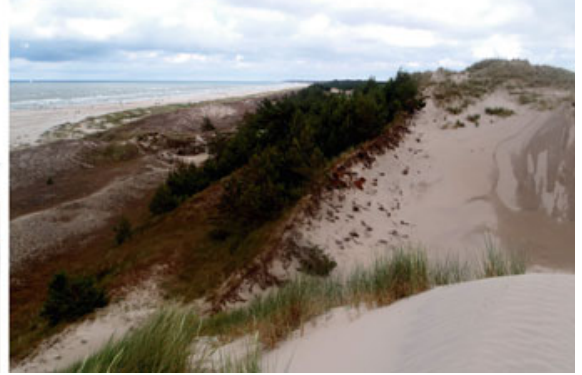

Fig. 20.2 (continued)

parallel to the coastline. The ridges are generally no higher than $8 \mathrm{~m}$, but where uplift is slower, a few reach $20 \mathrm{~m}$. The south-western coast of Finland near the Åland Islands has many skerries, forming a huge archipelago. In total, there are some 73,000 islands along the coast of Finland.

\subsubsection{Sweden}

The Swedish coastline is over $13,500 \mathrm{~km}$ long. Due to continuous uplift in the northern section, only the southern part of the Skåne coast is at risk of erosion (Fig. 20.2d). The present rate of land uplift by isostatic rebound varies from zero in southern Skåne to a maximum of $0.9 \mathrm{~mm}^{\text {year }}{ }^{-1}$ along the coast of the Bothnian Bay (Hanson 2002, see also Chap. 9 and references therein). Low coasts dominate in Sweden and active cliffs cut into tills and fluvioglacial sediments are found in the south of the country. The rest of the coastline comprises low or average height cliffs made of hard rock, partly covered by glacier deposits such as till, sand or gravel. The northern part of the Bothnian coast is mainly low lying and comprises igneous rocks and gravel. In Sweden, coastal dunes mainly occur on the southern coast in Skåne and Halland (Malmö-Ystad) and in spots along the Gulf of Bothnia on low coastal areas and small barrier islands or spits among the cliffs. The dunes reach heights of $10-15 \mathrm{~m}$ as ridges parallel to the coastline. The counties most affected by coastal erosion are Skåne, Blekinge and Halland (European Commission 2004).

\subsubsection{Denmark}

The Danish coastline of the Baltic Sea varies in shape and origin. In some places, the coast is formed by cliffs ('klints'), as in the southern part of the island of Zeeland. One of the famous Cretaceous-Tertiary klints occurs south of Copenhagen - a 14-km-long rocky cliff formation, mainly of chalk and limestone with Quaternary deposits on top. In other places, Quaternary deposits form the cliff with klint 
structures below ground (Prior 1977). Salt marshes, also called meadows, sink at a rate of $1-2 \mathrm{~mm} \mathrm{year}^{-1}$. Danish coastal systems are subject to erosion at rates of up to 3$5 \mathrm{~m} \mathrm{year}^{-1}$ (Clemmensen et al. 2011). The islands of Gotland (Sweden) and Bornholm (Denmark) are mainly formed from rock with small areas of coastal sand dunes.

\subsubsection{Germany}

Two-thirds of the German Baltic Sea coastline is being eroded. The coastline is divided between the two German states of Schleswig-Holstein in the west and Mecklenburg-Vorpommern in the east. The Schleswig-Holstein coastline is $637 \mathrm{~km}$ long with 148-km-long soft cliffs and is generally in a retreat state due to sea-level rise (Hofstede 2008). The Mecklenburg-Vorpommern coastline is almost $1945 \mathrm{~km}$ long in total with an external coast of $376 \mathrm{~km}$; of the latter, steep cliffs cover $128 \mathrm{~km}$ and flat sections $248 \mathrm{~km}$. Approximately $70 \%$ of this coast is in recession (Gurwell 2008). More than half of the coastline is 'bodden' coast-shallow bays and inlets cutoff from the sea by islands, peninsulas and spits (Sterr 2008). This coast was shaped during and after the last glaciation, with prevailing glacial and postglacial features and sediments, with low and soft cliffs. Natural coastal dunes are rare on the German Baltic Sea coast, and those that do occur are mostly found on the Darss Peninsula, Usedom Island and Rügen Island. The Darss Peninsula is a sandy spit covered by parallel ridges separated by wet, low depressions. Among these are sandy barriers that have developed as separate islands, like Hiddensee which is built from marine and aeolian deposits. These structures of marine origin have developed by longshore transport of eroded soft moraine cliffs. Small dunes have developed on low parts of Rügen Island, mainly on the beaches, and are derived from fluvioglacial deposits and chalk rocks. The chalk cliffs are unstable (Wahle and Obst 2009) and mainly covered by typical moraine deposits (Fig. 20.2e). The south of Rügen Island is formed by low, soft cliffs made from tills and clays, covered by sands. Some cliffs on Usedom Island reach heights of $50 \mathrm{~m}$. In other places, low coastal cliffs are formed from bottom moraine deposits. The remainder of the German Baltic Sea coast is formed by moraine cliffs with an average height of 5-15 $\mathrm{m}$ and fronted by narrow beaches. Among them are lowland areas with wetlands - salt marshes or coastal meadows. This type of coast has vegetation typical of swampy saline areas. In coastal areas with low hydrodynamic stress (common in bodden areas), peatlands may develop and reed beds may replace the beach (Lampe and Janke 2002). In places where the coast is formed of low-lying valleys, as between Kiel and Heiligendamm on the western German Baltic Sea coast, many coastal sections are protected by artificial dykes (Fig. 20.2i).

\subsubsection{Poland}

The Polish coast is aligned and formed of loose sediments with beaches up to $35 \mathrm{~m}$ wide on average. Extensive dune fields formed after the glacial recession can be found on the Polish coastal plains, where sandy dunes cover over $80 \%$ of the 500-km-long coastline ( abuz 2005). The dune fields are mainly situated in the direct vicinity of the coast but may reach $4 \mathrm{~km}$ in width and incorporate inland dunes, formed by sands transported by wind from the beach or fluvioglacial deposits. These are usually aeolian sand dunes forming transgressive ridges. The highest dune is $56 \mathrm{~m}$, with the highest wandering dune $42 \mathrm{~m}$; both on the Łebska Sandspit (Fig. 20.21). The coastal dune fields usually have a cliffed seaward slope with beaches in front (Fig. 20.2k). In several places, the depressions separating individual dunes on the dune coast are over $5 \mathrm{~m}$ deep. In such places, the land is threatened by flooding due to heavy precipitation, ice melt or storm surges. To protect low-lying areas, coastal dunes in Poland need to be $4.6-4.8 \mathrm{~m}$ in height and beaches need to be $2-2.5 \mathrm{~m}$ in height after nourishment (Boniecka and $\mathrm{Za}$ wadzka 2006). One-third of the sandy coast is formed by typical parallel coastal ridges, most of them eroded. Elsewhere, accumulation due to long-shore currents transporting sediments from eroded cliffs results in the development of beaches $60 \mathrm{~m}$ wide or more. Accumulative tendencies are seen on the Swina Gate Sandspit, at the end of the Hel Peninsula, at the mouth of the Vistula River or on the Łebsko Lake Sandspit (Labuz 2005). Foredunes of less than $10 \mathrm{~m}$ in height are still developing in these places. Soft Quaternary moraine cliffs cover $65 \mathrm{~km}$ of the Polish coast, among them high formations (up to $95 \mathrm{~m}$ ) of glacial deposits (tills and clays) covered by fluvioglacial sand (Fig. 20.2g) and lower formations of till covered by limnic and organic deposits (Subotowicz 1982). The longest sections of moraine cliff occur along the western part of the coast, and locally on its eastern part. Reed habitats are found on the banks of lagoons and lakes and also along Puck Bay. The Vistula Sandspit is bordered by lowland depressions and the mouth of the largest southern Baltic river, creating a typical sandy deltaic coast in Gdańsk Bay. Low-lying areas of $3 \mathrm{~m}$ above mean sea level (amsl) or less are vulnerable to sea-level rise and are at risk of flooding or ground water soaking (Rotnicki and Borówka 1990). Washover fans marking storm surges develop up to $3.5 \mathrm{~m}$ amsl (Labuz 2012).

\subsubsection{The Kaliningrad Region (Russian Federation)}

The eastern Baltic Sea coast comprises a range of soft, low moraine cliffs and low sandy coasts with sand dune fields. The only significant sand barriers are the Vistula and 
Curonian sandspits, the longest on the Baltic Sea coast, which have largely eroded foredunes and partly stabilised large sandy dunes (Boldyrev et al. 2010). The Vistula Sandspit is shared by Poland and the Kaliningrad region of the Russian Federation. The Curonian Sandspit stretches from the high, unstable moraine coastal cliffs of the Sambian Peninsula (Fig. 20.2h) in the Russian Federation to the channel of the Curonian Lagoon near Klaipeda in Lithuania. This part of the Russian Baltic Sea coast is mostly being eroded, with the rate of erosion accelerating in recent years (Chubarenko et al. 2009; Boldyrev et al. 2010).

\subsubsection{Lithuania}

The Lithuanian coastline is $160 \mathrm{~km}$ long and has large shifting sand dunes stretching for about $70 \mathrm{~km}$, mainly on the Curonian Sandspit, bordering low-lying land along the Curonian Lagoon. The sea front is a sandy beach up to $80 \mathrm{~m}$ wide. The proper coastline of $90 \mathrm{~km}$ in length (Povilanskas $2002 \mathrm{~b}$ ) is mainly formed of coastal dune ridges up to $10 \mathrm{~m}$ high. Some dune sections are being eroded by storms. Between 1990 and 2003, accumulative coasts decreased from 40 to $11 \%$, while erosive stretches increased to $27 \%$ (Mileriené et al. 2008; Jarmalavičius et al. 2012). The highest annual retreat exceeds $2.2 \mathrm{~m}$.

\subsubsection{Latvia}

The Latvian Baltic Sea coast is about $497 \mathrm{~km}$ long. The coast on the Baltic Proper is $183 \mathrm{~km}$ long and mainly exposed to the west, with the remainder in the Irbe Strait and Gulf of Riga (Eberhards 1998, 2003). The Baltic Proper coast and the western and southern coasts of the Gulf of Riga comprise soft cliff face formed by Quaternary deposits (Eberhards 2003). Hard, rocky cliffs of 4-6 m in height formed of Devonian sandstone and siltstone and covered by Quaternary deposits are found along the Vidzeme coast of the Gulf of Riga (Eberhards 2003; Koltsova and Belakova 2009). Dune coasts (Fig. 20.2j) can also be found, mainly in the Gulf of Riga. Almost $69 \%$ of the Latvian coast is highly vulnerable to erosion (Eberhards 1998, 2003).

\subsubsection{Estonia}

Land uplift has created a series of different landforms along the $3800 \mathrm{~km}$ of Estonia's coast. Most of the coastal area of Estonia emerged from the regressive sea and had a deficiency of sediment drift, and coastal formations are therefore low (Ratas et al. 2011). Coastal dune landscapes covering about $200 \mathrm{~km}^{2}$ are found behind sandy beaches along $340 \mathrm{~km}$ of the coast (Ratas et al. 2008). Dunes mainly develop where river mouths or deltas provide sand and are typically low ridges 2$8 \mathrm{~m}$ high and $30 \mathrm{~m}$ wide. Due to land uplift (2$2.5 \mathrm{~mm} \mathrm{year}^{-1}$ ), coastal dunes are found inland of the present coastline (Vallner et al. 1988). Most of the Estonian coast is low-lying and covered by moraine deposits with developing coastal meadows, gravel shores and a silty and low limestone coast (Fig. 20.2c). The largest Estonian islands, Hiiumaa and Saaremaa, are 1-10 m amsl with narrow gravel beaches and spits, with visible erosion and movement of low spits ( $\mathrm{Su}-$ ursaar et al. 2008). The northern coast located on the Gulf of Finland comprises numerous peninsulas and bays, shaped in rocks with many small beaches of pebbles and sand. The north-eastern coast, where the coastline is mainly straight with some forelands building shore and shore face, is mostly sandstone and limestone cliffs of up to $56 \mathrm{~m}-\mathrm{klint}$ (Fig. 20.2f). The Estonian coast is young and develops quickly due to uplift. Prograding beaches are stable but lacking sediment and are vulnerable to storm surges.

\subsubsection{Russian Federation}

The Russian coast to the south of the Gulf of Finland is mainly formed of low peninsulas built of moraine deposits with boulders in some places, and covered by unconsolidated sand. Beaches are narrow, consisting mainly of gravel and boulders. The northern coast is characterised by a very stable coastline mainly formed of bedrock formations. The southern sedimentary coast developed rapidly under wave action. Significant amounts of ice form every winter in the Gulf of Finland. Neva Bay, $21 \mathrm{~km}$ long, is a naturally low area of swampy meadows. Due to risk of flooding, a dam was built across Neva Bay to protect the low coast around St. Petersburg (Orviku et al. 2003). The northern coast of the gulf is higher with some sandy deposits on moraine and older bedrock.

\subsection{Erosion of Specific Coastal Types in Relation to Climate Change}

This section describes the erosion of different coastal types in the Baltic Sea region: forelands, beaches, coastal meadows, wetlands, sand spits, dunes, moraine soft cliffs and rocky coasts. Figure 20.3 shows the geographical distribution of the main coastal types.

\subsubsection{Forelands and Beaches}

Forelands (or promontories) are low-lying areas between the waterline and higher elevations further inland that are 
extended towards the sea. They may be rocky, till, gravel or sandy platforms that are formed by storm surges cutting into land deposits. Forelands are mainly present on rocky coast and accompanied by bays indented in the land. They can be found in the south-western and northern parts of Baltic Sea basin. The beach is an accumulative landform, formed by silt, sand or gravel deposited in the coastal zone. Beach shape and morphological parameters such as width or height provide information about coastal processes and development.

The low-lying part of the Baltic Sea coast is vulnerable to sea-level rise (see Chaps. 9 and 14). For instance, the spectacular sandy beaches of Estonia between Narva-Joesuu and Merikbila have already suffered damage from strong storms in recent decades. One likely cause is the decline in sand supply from the Narva River since it was dammed in 1956 and a hydropower plant built (Kont et al. 2008). Estonian beaches are already shrinking due to an increase in storm frequency (Orviku et al. 2003, see also Chap. 4). Spits still develop occasionally, but erosion now prevails due to major storms such as those in 2005 and 2007 (Tõnisson et al. 2008). Gravel and pebble beaches on Saarema Island were strongly affected by the January 2005 storm Gudrun and the storm resulted in beach deposits being moved inland by
15-30 m (Tõnisson et al. 2008). The shoreface was covered in boulders and accumulation was observed in shallow lagoons.

Despite isostatic uplift, the erosion of sandy beaches has prevailed throughout Estonia in recent decades: in some places the sea has even advanced inland, with beach erosion reaching $1.5 \mathrm{~m} \mathrm{year}^{-1}$ (Orviku et al. 2003). With no evidence of rising sea level, the observed beach erosion must be largely due to the recent increase in storm frequency in the eastern Baltic Sea and the decline in protective sea ice. Westerly and south-westerly storm winds in autumn and winter can raise sea level up to $2.6 \mathrm{~m}$ above the summer level (Kont et al. 2008).

In Latvia, cuts in coastal Quaternary deposits and sandstone also mark an increase in erosion processes (Eberhards et al. 2006). Some Lithuanian beaches have recently vanished due to westerly storm surges (Povilanskas 2002a; Dailidiene et al. 2006). Near Palanga and Olando Cape, coastline sediment loss reaches maximum values of almost $180 \mathrm{~m}^{3} \mathrm{~m}^{-1}$ (Žilinskas 2005). The height of Lithuanian beaches is 2.6-3.2 m (Jarmalavičius et al. 2012). Between 1993 and 2008, there was no visible beach recession but the coastline retreated by $10 \mathrm{~m}$ on average (Jarmalavičius et al. 2012). Coastal protection measures are currently used to
Fig. 20.3 Coastal types in the Baltic Sea region. A Soft moraine cliffs; $B$ Sandy barriers and sandy dunes; $C$ Rocky cliffs; $D$ Skerries; $E$ Low coast, meadows, organic/ wetlands

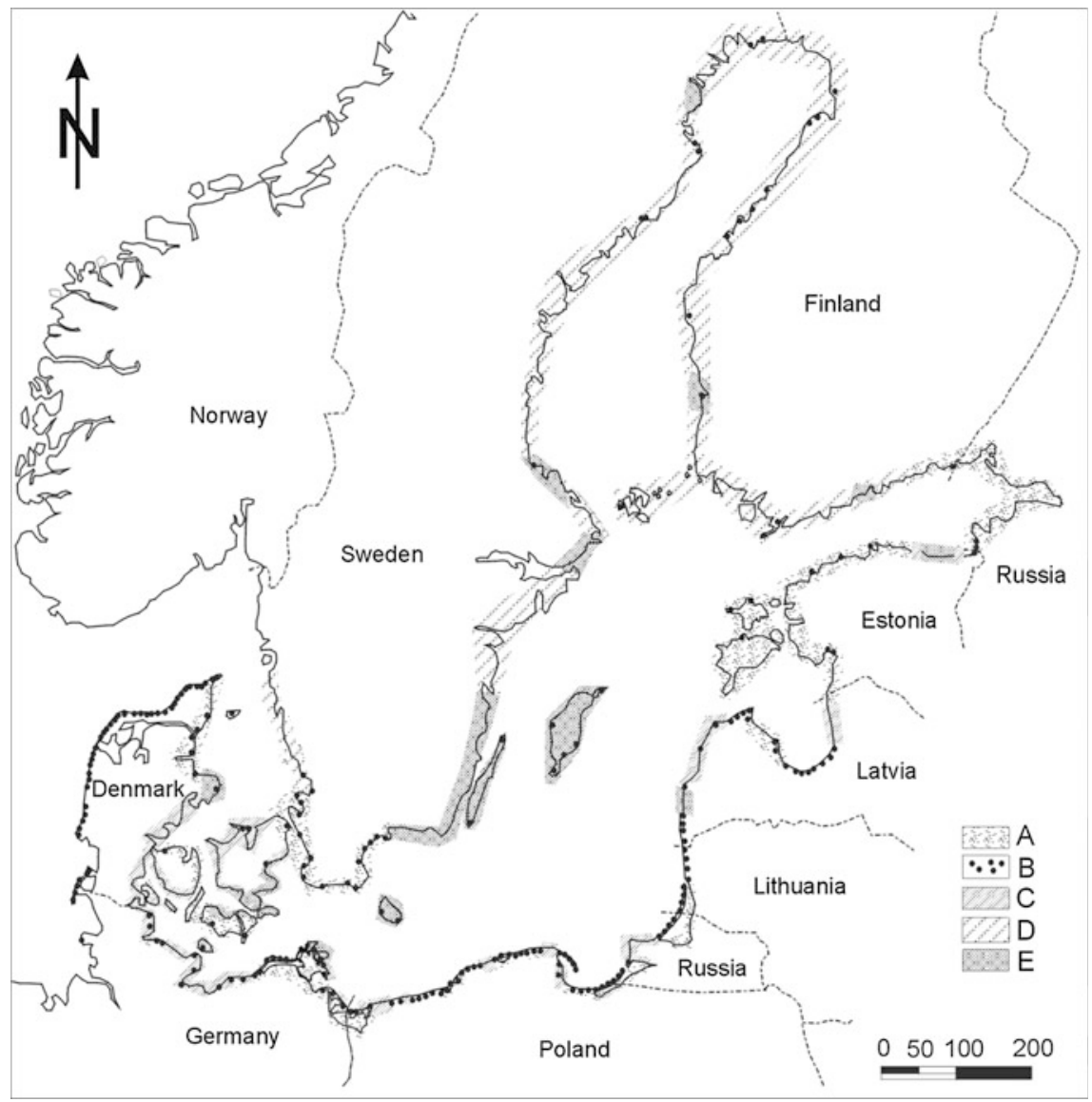


prevent land erosion near Palanga and other coastal resorts (Žilinskas et al. 2006).

Beaches in the Kaliningrad region have become narrower: decreasing from 25-40 $\mathrm{m}$ in 1984 to 5-15 $\mathrm{m}$ in 2000 (Gurova 2004). Near Sokolniki, there was an accumulative coast with a 20 -m-wide beach and dunes of up to $5 \mathrm{~m}$ high. Now there is serious erosion of the coast and a vanishing beach (Shishkina 2010). Average beach width in the Russian part of the $\mathrm{Cu}$ ronian Sandspit shrank by 10-20 m between 1984 and 2003 and height lowered by $0.2-0.5 \mathrm{~m}$ (Gurova 2004).

On the Polish coast, beaches lower than $3.5 \mathrm{~m}$ amsl are washed away by heavy storm surges each year (Labuz 2009a, b). The storm surge of 14 January 2012 reached $4 \mathrm{~m}$ amsl (Labuz 2014). Due to increasing storm frequency in recent decades (see Chap. 4), longer sections of beaches require replenishment. Coastal towns which experienced annual erosion of $0.3-0.7 \mathrm{~m}$ now have a nourished beach (Boniecka and Zawadzka 2006). Storms with water levels higher than $0.7 \mathrm{~m}$ amsl erode the entire beach as well as the top of coastal dunes or cliffs. For storms such as those in 2001, 2004 and 2006, erosion can amount to 2-5 m (Musielak et al. 2007). During a storm surge with a water level $1.7 \mathrm{~m}$ amsl, the beaches of the Hel Peninsula were completely flooded. Almost every year, two-thirds of the Hel Peninsula beaches need replenishing. Between 2002 and 2012, beaches on the Polish part of the Wiślana Sandspit shrank in width by $12 \mathrm{~m}$ in total (Labuz 2012), and in the preceding 19-year period (1984-2001), beaches on the Russian part of the Wiślana Sandspit shrank by up to $18 \mathrm{~m}$ (Kobelyanskaya et al. 2009). Many sandy beaches along the Gulf of Finland have recently been severely damaged by frequent storm surges, despite extensive protective measures (Ratas et al. 2011).

At Flakket on the Danish island of Anholt in the Kattegat, the low foreland formed as a flat platform covered by gravel and sand had been enlarging up until 1934 due to uplift. Since then it has eroded at rates of up to $6.5 \mathrm{~m} \mathrm{year}^{-1}$. Beach-ridge sediments, formerly up to $500 \mathrm{~m}$ wide, have mostly disappeared on the north-west side of Flakket. Between 2006 and 2010, erosion rates of up to $10 \mathrm{~m} \mathrm{year}^{-1}$ were recorded (Clemmensen et al. 2011). Water levels of $1.02 \mathrm{~m}$ amsl reach parts of the foreland once a year; while levels of $1.63 \mathrm{~m}$ amsl during storm surges (return period 20 years) affect the entire structure. Wave erosion has led to rapid coastal retreat and in the area immediately east of the local harbour a short stretch of shoreline is now only $25 \mathrm{~m}$ from the island's main road. Erosion rates elsewhere along the dune shores in the Kattegat are up to $2 \mathrm{~m} \mathrm{year}^{-1}$ (Clemmensen et al. 2011).

\subsubsection{Coastal Meadows and Wetlands}

Coastal meadows and wetlands (marshes and mires) are mainly found in Estonia and to a lesser extent in Sweden,
Latvia and Finland. An increase in sea level should theoretically cause a change in the composition of the vegetation of Baltic Sea coastal wetlands (Vestergaard 1997) and gradually displace them in an inland direction. No data are available on accretion processes in low-tidal meadows like those found along the Baltic Sea coast. Loss of meadow area will depend on the relation between the rate of sea-level rise and the rate of accretion. If accretion keeps pace with sea-level rise, then no loss will occur; if accretion is less than sea-level rise, then the loss will start from the seaward edge of the meadow. A third consequence of sea-level rise may be increased wave erosion along the seaward edge of the meadow that will tend to narrow the lower meadow (Vestergaard 1991).

Sea-level rise could strongly affect Estonia, due to its long coastline and extensive low-lying coastal areas, although the land uplift rate is higher here than in the south-western part of the Baltic Sea basin. Estonian coastal wetlands and mires are already shrinking due to climate change (Kont et al. 2007). Flat- and low-lying coastal zones that experience isostatic and tectonic uplift should be stable, despite the activation of coastal processes, presumably due to global climate change, that has been observed in Estonia since the mid-1970s (Orviku et al. 2003). A hypothetical $1 \mathrm{~m}$ rise in global sea level would roughly reinstate the coastline position of the $1700 \mathrm{~s}$, forcing local plant communities to migrate inland (Kont et al. 2008) and would submerge many small islands. The Estonian coast shows frequent sea-level fluctuations due to changes in the precipitation/evaporation balance, river discharge and storms, but no evidence of a long-term rise in sea level (Kont et al. 2008). Westerly and south-westerly storms can cause short-term surges and extensive flooding on the Estonian coast (with maximum storm surges of $2.53 \mathrm{~m}$ above the Kronstadt zero), whereas the highest water-level rise in the open sea rarely exceeds $2.0 \mathrm{~m}$ (Kont et al. 2008, see also Chap. 9). On erodible shores, the fine-grained fractions are entirely washed out during a surge. However, the shingle ridges and boulder fields that remain are extremely resistant to further erosion. Virtsu, an important port connecting the Estonian mainland with the islands of Saaremaa and Muhu, is expected to undergo significant change. The peninsula upon which Virtsu is situated could eventually be divided into many islets. A rise in sea level of $72 \mathrm{~cm}$ (in the north) to $80 \mathrm{~cm}$ (in the south) would inundate more than $76 \mathrm{~km}^{2}$ of Estonian territory, including all reed beds and most coastal meadows. Several plant communities and biotopes of rare speciesincluding unique orchids-would disappear (Kont et al. 2008). In the absence of coastal protection measures, an inland migration of coastal landforms and plants would be inevitable. The areas most vulnerable to sea-level rise in the coastal wetlands near Pärnu are flooded during storms (Kont et al. 2007). The Estonian lowland may be affected by flooding up to $300 \mathrm{~m}$ inland. Such areas may need special 
protection, as sea-level rise would have socio-economic impacts, particularly on recreational areas. Water impact on the sandy coastal zone has long been observed in many sections of the eastern Gulf of Finland (Orviku et al. 2003). The high rate of coastal erosion results from the specific features of this water area, such as the morphology, shallowness and local wave field (Ryabchuk et al. 2009).

Rising sea level causes a landward shift in the meadows and a growing thickness of the organic material, whereas a fall in sea level leads to surface drying and mineralisation and a lowering of its surface; described for the German coast by Lampe and Janke (2002). Moreover, black peat layers have developed due to peat oxidation caused by a fall in either groundwater or sea level. Coastal meadows located no higher than $0.5 \mathrm{~m}$ amsl on the German coast seem to be in greater danger than those in Estonia.

The eastern part of the Gulf of Finland is especially prone to coastal flooding during westerly storms. The highest recorded flood in St. Petersburg occurred on 7 November 1824, when the water level reached $4.21 \mathrm{~m}$ amsl (Kurennoy and Ryabchuk 2011). During the storm Gudrun (January 2005, Tõnisson et al. 2006), an early forecast for the maximum surge in St. Petersburg was $3.7 \mathrm{~m}$. Even floods not exceeding 1.9-2.2 m caused extensive coastal erosion and sediment resuspension in many coastal areas near St. Petersburg when accompanied by strong wind waves. Such events are particularly damaging to the coastal zone as they hinder the recovery of beaches, destroy buildings along the coast and lead to unrecoverable dune erosion, as seen in the eastern Gulf of Finland (Ryabchuk et al. 2009). A significant increase in annual and winter storm frequency in the latter half of the twentieth century has been observed in the Gulf of Finland (Orviku et al. 2003, see also Chap. 4). Low-lying coastal areas in Finland (e.g. Helsinki) are also at risk of flooding during heavy storm surges like the one in 2005.

\subsubsection{Sandspits and Coastal Dunes}

Sandspits are coastal deposition features commonly found from the south-western to the south-eastern parts of the Baltic Sea coastline. The predominance of westerly winds is shaping coastal dunes that develop on sandy shores from sand delivered from wide beaches. The last extreme event caused by westerly winds was in December 2013, when hurricane Xavier rebuilt southern Baltic Sea coastal beaches and dunes. These east-blowing winds are also responsible for developing storm surges causing coast erosion on the Curonian Spit (Lithuania and Russia); near Zelenogradsk the erosion rate is $0.69-0.79 \mathrm{~m} \mathrm{year}^{-1}$ (Fedorova et al. 2010). Heavy erosion was recorded after hurricane Anatoly on 4-5 December 1999 on the west-facing sandy coasts in Lithuania, Latvia, Russia and Estonia.
Lithodynamical processes along the sandy Lithuanian coast have changed over the past couple of decades due to ever-stronger storm surges (Visakavičius et al. 2010). The storms of 2-6 October 2006 washed away the foredune north of Palanga Pier. In Poland, this storm caused heavy coastal erosion on 1 October, with a dune retreat of 5-8 $\mathrm{m}$ (Labuz and Kowalewska-Kalkowska 2010). Estonian coastal dunes erode due to coastal retreat, as shown by several studies (Ratas et al. 2008). The storm Gudrun (9 January 2005) caused a surge of $2.75 \mathrm{~m}$ in Pärnu, Estonia. Erosion on Saaremaa Island, Pärnu Bay and the Gulf of Finland was significant after this event (Tõnisson et al. 2006). Near Tallinn, the beach lowered and dune retreat was up to $5 \mathrm{~m}$. The erosion due to this storm was ten times greater than that during the previous 20 years. High surges on the Russian coast of the Gulf of Finland in autumn 2006 and winter 2007, with water levels $2 \mathrm{~m}$ amsl, totally changed the dunes in cut-off cliffs of up to $2 \mathrm{~m}$ high (Ryabchuk et al. 2011).

The sandy Latvian coastal zone has changed considerably in recent decades, presumably due to global warming, anthropogenic factors and increasing storm damage (Eberhards and Saltupe 1995). The sandy coastline of the Gulf of Riga was particularly strongly affected by erosion and recession during extreme storms in 1992 and 2001, with dune erosion of $20-30 \mathrm{~m}$ in a single storm event (Povilanskas 2002a). Detailed studies show that erosion is more frequent than accumulation along the Latvian coast, with loss rates of 3-14 $\mathrm{m}^{3} / \mathrm{m}$ per year (Soomere et al. 2011). For the Baltic Proper, the mean rate of shore retreat is 3$8 \mathrm{~m} \mathrm{year}^{-1}$, with a maximum of $10-18 \mathrm{~m} \mathrm{year}^{-1}$ or more (Eberhards 2003). Coastal dune retreat in Latvia following Hurricane Erwin in January 2005 was 1.5-7 m on average, with a maximum of $15 \mathrm{~m}$ north of Liepaja (Eberhards et al. 2006). The only and longest section with accumulative tendencies is on the western coast of the Kurzeme Peninsula.

The Polish coast is mainly formed of soft sandy sediments, with an average rate of retreat of $0.5-1.5 \mathrm{~m}^{\text {year }}{ }^{-1}$ (Zawadzka-Kahlau 1999). Dunes of up to $4 \mathrm{~m}$ in height are washed out or reduced by storm surges along the Polish coast. Behind them, storm washover fans in interdune depressions are a strong indicator of storm erosion ( $\mathrm{Labuz}$ 2009a). In 1995-2009, two to three storms per season completely washed away the low, new foredunes in places where the beach was less than $3 \mathrm{~m}$ amsl (Łabuz 2009a). In 2001-2004, storms caused greater dune retreat than the longterm annual mean for the Polish Baltic Sea coast (Musielak et al. 2004). The storm surge of 23 November 2004 caused severe erosion of up to $7 \mathrm{~m}$ in the western part of the Polish dune coast ( abuz and Kowalewska-Kalkowska 2011). Dune erosion during the storm surge in October 2009 exceeded 5-9 m (Łabuz and Kowalewska-Kalkowska 2010). In recent years, foredunes have been heavily eroded along the western Polish coast (Dudzińska-Nowak and 
Furmańczyk 2009; Łabuz 2009b; Furmańczyk et al. 2011). On the central and eastern coast, the maximum retreat of sand dunes was 1-2 $\mathrm{m}$ year $^{-1}$ (Zawadzka-Kahlau 1999). Today erosion after each storm surge reaches 3-6 m; extreme erosion after storms in 2009 and 2012 reached $6 \mathrm{~m} \mathrm{year}^{-1}$. Low coastal dunes were completely washed away and in some places need replacing by artificial dikes or concrete walls. The situation is similar along more than twothirds of the Hel Peninsula, where beach nourishment, groynes and other measures protect the narrow land against flooding. Coastal dunes on the Wiślana Sandspit along the Polish and Russian section were eroded in autumn and winter of 2006 and 2007 (Kobelyanskaya et al. 2009). Other studies show the Wiślana and Curonian spits to be continuously eroded, with a recent increase near the Baltyjsk Strait (Volkova et al. 2004; Chubarenko et al. 2009). The heavy storm surge of 2012 caused dune retreat of up to $5 \mathrm{~m}$ on the Wiślana Sandspit near the Polish-Russian border, and substantial erosion in the eastern and middle parts of the Polish coast (Łabuz 2014). The exposed western Lithuanian coast is also strongly threatened by storm surges (Dailidiene et al. 2006). Erosion has totally consumed the foredunes along the Curonian Sandspit over past couple of decades.

The German Baltic Sea sandy coast between Warnemünde and Darss Peninsula is eroding rapidly (Kortekaas et al. 2010). Near Warnemünde and on the west coast of Darss, erosion has reached $3 \mathrm{~m}$ since the mid-twentieth century (Kortekaas et al. 2010), probably due to heavy waves attacking the exposed west coast in winter. The November 1995 storm event caused material loss from the sandy shores of Usedom Island (Schwarzer et al. 2003). The situation was similar on the western and central Polish coast, where sea level reached $2 \mathrm{~m}$ amsl and coastal dunes retreated 5-10 m (Labuz 2005). Erosion along the dune shores in the Kattegat is up to $2 \mathrm{~m} \mathrm{year}^{-1}$ (Clemmensen et al. 2011).

\subsubsection{Moraine Soft Cliffs}

The moraine soft cliffs of the Baltic Sea region were formed during the last ice age and mainly extend from the southern (Denmark, Germany, Poland and southern Sweden) to the south-eastern coastline (Kaliningrad region and part of Latvia and Estonia coast).

The high soft cliffs of the Sambian Peninsula (northwest of Kaliningrad) erode at least 1-1.5 $\mathrm{m}_{\text {year }}{ }^{-1}$, with a maximum of up to $10 \mathrm{~m}$ year $^{-1}$, and rates have increased over the past decade (Chubarenko et al. 2009). Along the Latvian or Lithuanian coast, the average rate of retreat may be 1$2 \mathrm{~m} \mathrm{year}^{-1}$ (Povilanskas 2002a; Eberhards 2003). In Latvia, the long-term mean rate of cliff retreat was $0.5-0.6 \mathrm{~m}_{\text {year }}{ }^{-1}$ in the latter half of the twentieth century, reaching a maximum of 1-1.5 m year ${ }^{-1}$ along particular stretches $10-20 \mathrm{~m}$ high (Jūrkalne area). After 1980/1981, rates of coastal retreat became two to five times higher, reaching $1.5-4 \mathrm{~m} \mathrm{year}^{-1}$ (Eberhards and Saltupe 1995). Soft cliffs in Latvia retreated 0.5-4 $\mathrm{m}$ on average after the storm surge of Hurricane Erwin in January 2005 (Eberhards et al. 2006). The severe storms of 1993, 1999 and 2001 each caused a coastal retreat of 3$6 \mathrm{~m}$, with a maximum of up to 20-30 $\mathrm{m}$ at the dune coast of Cape Bernāti (Eberhards 2003).

Cliff dynamics along the Polish Baltic Sea coast indicate that the main erosion factors are rainfall and storm surges, with cliff erosion rates of up to $1.5 \mathrm{~m} \mathrm{year}^{-1}$ (Subotowicz 1982; Zawadzka-Kahlau 1999; Florek et al. 2008). Cliffs may become unstable when the toe is undercut by waves (Prior 1977). Cliff retreat is also related to intense rainfall triggering landslides. Mudslide debris discharged from the cliff slope channels onto the foreshore and forms elongated rounded lobes, helping cliff retreat. Slides are usually caused by high water content in the soil after heavy rain. Landslides caused by heavy rain occurred in 2007 and 2009 on the western Polish coast. On the German Baltic Sea coast, the average rate of shoreline retreat is about $0.4 \mathrm{~m} \mathrm{year}^{-1}$ (Sterr 2008). Sea-level rise is expected to increase cliff erosion on the German coast and to increase the supply of sediment to the coastal zone (Hoffmann and Lampe 2007). Today, the maximum retreat on the western part of the coast is $2.5 \mathrm{~m} \mathrm{year}^{-1}$ at Heiligenhafen, near which marine accumulation creates a sandy spit (growth 2-3 m year ${ }^{-1}$, Hofstede 2008). One of the highest rates of cliff abrasion in Germany is in the area of the Streckelsberg scarp, on the outer shoreline of Usedom, as shown by comparing the old Swedish map of 1695 with a map for 1986. Maximum coastal retreat here exceeds $300 \mathrm{~m}$ (Schumacher 2002). The mudslides of the Eocene cliff clays in Denmark are also connected to climatic events (Prior 1977). Landslides extend up to 300-400 m inland. The combination of high water levels and strong wind has often resulted in severe damage to the soft cliffs coast of the Ystad municipality. In southern Sweden, the soft moraine cliffs have retreated 1$1.5 \mathrm{~m} \mathrm{year}^{-1}$ over the past 150 years (Hanson 2002). The highest Baltic moraine cliffs of Wolin Island in Poland are retreating due to storm surges by $0.3-1.5 \mathrm{~m} \mathrm{year}^{-1}$ (Kostrzewski and Zwoliński 1995).

\subsubsection{Rocky Coasts and Hard Cliffs}

Rocky cliffs in Sweden and Finland are resistant to marine erosion and are mainly formed from hard granites. The Latvian low cliffs of hard sandstone, covered with a thin layer of Quaternary deposits, are eroded on average by over $0.5 \mathrm{~m} \mathrm{year}^{-1}$ by westerly storm surges (Eberhards 2003). Danish and Estonian klints are eroded by storm surges but also by weathering of chalk and limestone. In Denmark, cliff 
erosion reaches $0.5 \mathrm{~m} \mathrm{year}^{-1}$. The German chalk cliffs on Rügen Island also erode, with landslides occurring after heavy rain. The maximum retreat of the Jasmund chalk cliff is over $1 \mathrm{~m} \mathrm{year}^{-1}$ (Lampe 1996).

\subsection{Potential Climatic Threats to Coastal Areas}

Climate-related ocean-atmosphere oscillations, such as the North Atlantic Oscillation (NAO) in the northern hemisphere, can lead to coastal changes (Viles and Goudie 2003). In recent decades, an increase in North Atlantic storm frequency has been linked to a strongly positive NAO index (Chap. 4). Many coasts experience erosion and habitat loss but only a few studies clearly define the relationship between observed coastal land loss and the rate of sea-level rise (Zhang et al. 2004). Although many studies have shown that periods of increased storminess increase coastal erosion and change, it is not always possible to relate increases in coastal storm frequency to specific modes of climatic variability (Viles and Goudie 2003).

\subsubsection{Sea-Level Rise}

Sea-level rise within the Baltic Sea is well documented (Richter et al. 2007, Chap. 9). Sea-level rise is being observed at coastal stations along the southern Baltic coast up to the southern part of Estonia in the east and in southernmost Sweden in the west (Harff and Meyer 2007, Chap. 9). On the Polish coast, sea-level rise was 0.6$1.5 \mathrm{~mm} \mathrm{year}^{-1}$ in the last century but increased to $2.2-$ $3.9 \mathrm{~mm} \mathrm{year}^{-1}$ during the last 20 years (Pruszak and $\mathrm{Za}$ wadzka 2008, Chap. 9 and Fig. 9.7). The southern Baltic coast is sinking at a rate of $1-2 \mathrm{~mm} \mathrm{year}^{-1}$ (Siegel et al. 2004; Sterr 2008; Pruszak and Zawadzka 2008; Clemmensen et al. 2011).

Rising sea levels are expected to exacerbate coastal erosion in southern Sweden and to increase flood risk along its western and southern coasts. Rocky northern Sweden is less prone to flooding and erosion as the rise in sea level is being counteracted by land uplift. The settlements most affected by increased flood risk are along the Skåne coast and the town of Göteborg in Västra Götaland (European Commission 2004). In Poland, over half of the densely populated lowlying coast is threatened by sea-level rise (Rotnicki and Borówka 1990; Zeidler et al. 1995; Łabuz 2012).

Sand dunes may be affected by rising sea level, changes in erosion/accretion patterns and changes in groundwater level, as reviewed by Carter (1991). For dunes, the most likely response to changes in sea level is a two-way redistribution of the sand: seaward movement and deposition of eroded material below the new sea level, and landward sand drift resulting in new foredune growth behind the eroded dune as well as sand deposition on older dune land further inland. Groundwater level is a major factor in plant distribution in coastal dunes (Carter 1991) and may strongly influence dune slack vegetation. The sequence of soil moisture changes in dune slacks may, however, be modified by sand movements that change the shape of the dune system. As sea level rises, estuaries and lagoons attempt to maintain equilibrium by raising their bed elevation. This will change environmental conditions, increasing the threat to low-lying coastal areas such as marshes and wetlands. Some current areas of salt marsh and wetlands could decrease or even disappear. Saltwater intrusion and the resulting changes in coastal ecosystems are a problem in the northern Curonian Lagoon. An important area in this lagoon is the Nemunas River Delta, with its ecologically significant wetlands as well as agricultural land. Low coastal areas in Estonia are permanently under threat from rising sea level (Kont et al. 1997; Orviku et al. 2003). In Poland, low coastal areas behind dune belts on postglacial valleys or surrounding coastal lakes are threatened by future sea-level rise (Rotnicki and Borówka 1990). The land area up to 3-3.5 m amsl could be gradually flooded as sea level rises. These areas are widely distributed along the Polish and German coast and are used for agriculture and human settlements. Many lowlands on the German coast are vulnerable to sea-level rise; some densely populated (Sterr 2008). Coastal settlements are also at risk in Poland, Lithuania, Latvia and Estonia.

\subsubsection{Storm Surges}

The greatest storm surges on the southern Baltic Sea coast come from the north-east (Schwarzer et al. 2003; Kowalewska-Kalkowska and Kowalewski 2005; Pruszak and Zawadzka 2005). On the southern Baltic Sea coast, severe surges were recorded in January 2002 and 2012; November 1995, 2004 and 2006; and October 2009 (Schwarzer et al. 2003; Florek et al. 2008; Gurwell 2008; Łabuz 2009b, 2012). The most destructive storm surges to coastal areas are those with a water level $2 \mathrm{~m}$ amsl. The most catastrophic sea surges on the Polish coast overflow all relief forms lower than $3.5 \mathrm{~m}$. The eastern Baltic Sea coast is mainly affected by westerly storms (Žilinskas 2005; Visakavičius et al. 2010; Kelpšaitė and Dailidienè 2011; Soomere et al. 2011). The Lithuanian and Latvian coasts are exposed to the west and vulnerable to erosion. In Estonia, more extreme sea levels and storm surges are associated with warmer winters ( $\mathrm{Su}$ ursaar et al. 2003). Storms, driven mainly by westerly winds, change the position of pebble capes and other spits. Neva Bay in the eastern Gulf of Finland is open to the west, with one of the longest fetches in the Baltic Sea-up to $400 \mathrm{~km}$. 
Strong westerly storms cause a predominant drift to the east and erode the coast (Ryabchuk et al. 2011). At present, the coast in these countries is threatened more by major storm surges than by sea-level rise. Such surges were reported in November 2001, September 2004 and January 2005 and 2007 (Tõnisson et al. 2006, 2008; Suursaar et al. 2003, 2008; Koltsova and Belakova 2009; Dailidienè et al. 2011).

In the Gulf of Finland, the frequency of stormy days varied greatly during the latter half of the twentieth century, from a minimum in the 1960 s to a maximum in the last two decades (Orviku et al. 2003). Repeated floods were reported in 2004 2008 , with strong winds of $20-23 \mathrm{~m} \mathrm{~s}^{-1}$ causing ice jams, water damming and high waves (Kurennoy and Ryabchuk 2011). In Denmark, most storm damage occurs when water level rises at least $2 \mathrm{~m}$ (Sorensen et al. 2009). The Russian coast of the Gulf of Finland was totally changed after storms on 29 November 2006 and 11 January 2007 (Ryabchuk et al. 2011). Each storm surge reached a water level of 1.5-2 m amsl. In Lithuania, changes in the wind and wave regime in the latter half of the twentieth century intensified the natural sediment transport and accelerated coastal erosion or stopped accumulation processes (Kelpšaitė and Dailidienè 2011). Consequently, Lithuania is now more at risk of flooding due to storms (Visakavičius et al. 2010).

The extent of coastline erosion and retreat depends both on the height and duration of the sea surge. Storms of similar magnitude coming immediately after other storms may have much less geomorphic effect than those which occur in isolation (as all the geomorphic work will have been done by the preceding storms). This effect was observed in Poland between November 2001 and February 2002 with several storm surges in which shoreline retreat and dune sand volume erosion was in total comparable to the first two events in November. Similar situations occurred in 2006/2007 in Poland, Germany and in 2007 in Estonia and Russia. Alternatively, long clusters of storms may have a compounding, more serious geomorphic effect than would the same number of events operating in isolation (Viles and Goudie 2003). The combination of a major rise in water level in winter months together with the shortening of the ice season may significantly increase the frequency of events that had previously been very rare (Räämet and Soomere 2011). Specifically, an increase in the frequency of three factors together-high water level, rough seas and the absence of ice in the nearshore zone - may be responsible for the intense erosion of depositional coasts in the eastern Baltic Sea.

\subsubsection{Land Erosion and Habitat Loss}

Owing to storm effects, almost two-thirds of Polish coastal dunes are eroded (Zawadzka-Kahlau 1999; Pruszak and Zawadzka 2005; Łabuz 2009b). The $75 \%$ of the sandy coast with low-lying hinterland is at risk of flooding (Rotnicki and Borówka 1990; Łabuz 2012). Almost $75 \%$ of German sandy coasts are threatened by erosion (Sterr 2008). The situation is similar in Lithuania, Latvia and Estonia (Eberhards 2003; Milerienè et al. 2008; Ratas et al. 2008). Over $65 \%$ of the Latvian coast is eroded (Eberhards 2003). About $40 \%$ of the Russian Neva Bay coast has recently been heavily eroded (Ryabchuk et al. 2011). With no data between storm events it is hard to estimate when coastal changes occurred ( $\mathrm{Su}-$ ursaar et al. 2008).

Land erosion is highlighting the need for effective coastal protection measures. However, in some areas, so far accumulated coastline (mainly sandbars) is shrinking due to the use of coastal protection measures. This is because coastal protection measures used in one place may reduce the transfer of sand from land to longshore drift and thus its accumulation in another. This problem will increase, for example, in Poland where almost $6 \%$ of the coast has been stabilised over the past ten years.

Erosion reduces the area available for plant and animal communities. As a result, coastal habitats are likely to be highly sensitive to sea-level rise (Vestergaard 1991, Chap. 16). The entire vegetation of cliff slopes is threatened by repeated landslides. Many such habitats are listed in Natura 2000 (www.natura.org). Dune erosion also causes loss of valuable coastal habitats (Łabuz 2012, Chap. 16). As sand dunes develop beyond the direct influence of seawater, dune vegetation is less vulnerable to sea-level rise than coastal meadow vegetation.

\subsubsection{Precipitation and River Discharge}

Increasing precipitation will increase river flows and thus flooding in low-lying coastal areas. Levels of coastal lakes can vary greatly in response to changes in rainfall in their catchment and to changes in evapotranspiration. After the spring melt of 2010, large amounts of water from coastal swamps broke through the narrow dune belt near Kołobrzeg on the Polish west coast. Seawater entered the brackish environment, completely destroying this fragile habitat (Labuz 2012). Furthermore, increasing precipitation may increase river flows and encourage vegetation growth (Viles and Goudie 2003). Heavy rainfall is a destabilising factor for soft cliffs and caused landslides in Poland in 2007 and 2008 (

On the other hand, reduced river input to the southern part of the Baltic catchment in future (see Chaps. 5 and 12) could reduce the supply of sediment for beaches or spit rebuilding (Kont et al. 2008). River mouths reinforced by breakwaters hinder long-shore sediment movement, leading to sediment build-up on one side of the river mouth and a lack of sediment on the other. In recent years, beaches in western Estonia have become narrower due to a decline in run-off from 
rivers (Kont et al. 2008). As the beach is lost, fixed structures or coastal land nearby are increasingly exposed to the direct impact of storm waves and may be damaged or destroyed unless new protective measures are taken to disrupt these natural coastal processes.

\subsubsection{Ice-Cover Melt}

Decreased ice-cover duration in the Gulf of Finland in the recent past (see Chap. 8) has reduced the protection of coastal sediments during the stormy period (Ryabchuk et al. 2011), even though ice jams pushed onto land by waves may also cause erosion of dunes and cliffs. Ice jams were observed on the southern Baltic Sea coast in the winters of 1995, 2003, 2010 and 2011. Their impact was seen in narrower and lower beaches after ice melted in late spring. On the northern Baltic Sea coast, ice sheets may have a bigger impact on the coast. In February 2008 in Neva Bay, ice strongly eroded coastal land and human structures (Ryabchuk et al. 2011). On the other hand, declining ice cover in the northern Baltic Sea would mean greater potential for coastal erosion due to wave action.

\subsection{Conclusion}

The Baltic Sea coasts are already experiencing the adverse impacts of climate change, mainly due to changes in sea level and storminess. Coasts are particularly vulnerable to extreme events. The response of the coastal system varies over different timescales, owing to changes in local dynamics or geo-morphological conditions as well as to the intensity of the driving forces. Identifying the contribution of climatic change to geomorphic change can be difficult, and its importance will also vary regionally (Viles and Goudie 2003). The main drivers of change in coastal geomorphology are geological structural resistance, changes in sea level, long-shore currents and storm surges. These factors are responsible for both coastal erosion and accumulation, as well as for the emergence and variability of beaches. Coastal protection measures are major factors at the local scale. At the regional and global scale, coastal erosion is induced by an increasing number of severe storm surges and sea-level rise. These factors are leading to the following:

- loss of sediment for coastal rebuilding

- loss of valuable dynamic coastlines

- loss of coastal resilience

- loss of valuable natural habitats

- loss of economic value and private property

- unpredictable land change due to extreme storm events

- increasing cost to society in terms of coastal protection measures.
The impact of climate change on coasts is exacerbated by the increasing need for coastal protection by human activities (Bardach 1989; Beukema et al. 1990; van der Meulen et al. 1991). There are two main types of management strategy. The first is to stabilise the existing coastline and thus protect coastal and neighbouring areas from future change. The second, which is more resilient and depends on human adaptation to coastal change, accepts that in some places the coast would be not protected and would be left in its natural state. The costs for adapting to climate change are generally much lower than the costs of damage incurred through a lack of adaptation. Local communities are currently better prepared for extreme events; but still very few local administrations are attempting to estimate costs associated with the risks of future climate change. Projecting future costs is also complicated because different local authorities may prefer different coastal development and management policies, for example, for protection against coastal erosion. European projects such as ASTRA (Astra-project 2007), EUROSION (European Commission 2004), SINCOS (Richter et al. 2007) or MICORE (Ferreira et al. 2009) have provided new data and insights regarding storm effects on the Baltic Sea coast. Administrative borders in coastal areas and efforts for coastal protection differ among Baltic Sea countries, even between neighbouring nations. Some management actions are complicated by the morphodynamic changes caused by artificial coastal stabilisation in some places and its natural disruption in others. The coastal zone is a linear environment that knows no national or decision-making boundaries. Decadal-scale climatic change and variability may initiate a pulse of activity that results in a complex, nonlinear landscape response.

Open Access This chapter is distributed under the terms of the Creative Commons Attribution Noncommercial License, which permits any noncommercial use, distribution, and reproduction in any medium, provided the original author(s) and source are credited.

\section{References}

Astra-project (2007) Towards climate change adaptation in the Baltic Sea region - results of the case studies (www.astra-project.org). Accessed 15 January 2012

Bardach JE (1989) Global warming and the coastal zone. Climatic Change 15:117-150

Beukema JJ, Wolff WJ, Brouns WM (eds) (1990) Expected effects of climatic change on marine coastal ecosystems. Kluwer Academic Publishers, Dordrecht

Boldyrev V, Bobykina VP, Chubarenko BV, Burnashov EM, Karmanov KV (2010) Abrasion processes on the shores of south-eastern Baltic. In: Abstracts of the XXIII International Conference on Coastal Evolution Studies: Traditions and Modern Concepts. SaintPetersburg, Russia

Boniecka H, Zawadzka E (2006) Protection of the Polish coast by artificial nourishment. In: Tubilewicz A, (ed), Coastal Dynamics, Geomorphology and Protection, p 51-60 
Carter RWG (1991) Near-future sea-level impact on coastal dune landscapes. Landsc Ecol 6:29-39

Chubarenko B, Burnashov E, Boldyriev V, Bobkina V, Kormanov K (2009) Long-term changes in the rate of coastal erosion in the Kaliningrad Oblast (south-east Baltic). In: Abstracts of the International Conference on Climate Change: The Environmental and Socio-economic Response in the Southern Baltic Region, 25-28 May 2009, Szczecin, Poland, p 101

Clemmensen LB, Bendixen M, Nielsen L, Jensen S, Schrøder L (2011) Coastal evolution of a cuspate foreland (Flakket, Anholt, Denmark) between 2006 and 2010. Bull Geol Soc Den 59:37-44

Dailidiene I, Davuliene L, Tilickis B, Stankevicius A, Myrberg K (2006) Sea level variability at the Lithuanian coast of the Baltic Sea. Boreal Environ Res11:109-121

Dailidienė I, Davulienė L, Kelpšaitė L, Razinkovas A (2011) Analysis of the climate change in Lithuanian coastal areas of the Baltic Sea. J Coast Res 28:557-569

Dronkers J (2005) Dynamics of coastal systems. Advanced Series on Ocean Engineering 25. World Scientific Publishing Company, Hackensack, p 1-519

Dudzińska-Nowak J, Furmańczyk K (2009) A laser scanning application for volumetric changes of the beach and dune analyses. In: Abstracts of the International Conference on Climate Change: The Environmental and Socio-economic Response in the Southern Baltic Region, 25-28 May 2009, Szczecin, Poland, p 103

Eberhards G (1998) Coastal dunes in Latvia. Environmental perspectives of Southeast Baltic coastal areas through time. Riga, Latvia, p $18-25$

Eberhards G (2003) The sea coast of Latvia. Morphology Structure. Coastal Processes. Risk zone. Forecast. Coastal Protection and Monitoring. Latvijas Universitate, Riga, Latvia

Eberhards G, Saltupe B (1995) Accelerated coastal erosion-implications for Latvia. Baltica 9:16-28

Eberhards G, Lapinskis J, Saltupe B (2006) Hurricane Erwin 2005 coastal erosion in Latvia. Baltica 19:10-19

Ekman M, Mäkinen J (1996) Recent postglacial rebound, gravity change and mantle flow in Fennoscandia. Geophys J Int 126:229234

European Commission (2004) Living with coastal erosion in Europe: Sediment and space for sustainability www.eurosion.org/project/ eurosion_en.pdf

Fedorova E, Sviridova E, Marusin K, Khabidov A (2010) Remote and cartographical techniques for estimation of coastal erosion rate in seas and inland water bodies. In: Proceedings of the International Conference on Dynamics of Coastal Zone of Non-tidal Seas, 26-30 June 2010, Baltiysk (Kaliningrad Oblast, Russia), p 82-84

Ferreira O, Ciavola P, Armaroli C, Balouin Y, Benavente J, Del Rio L, Deserti M, Esteves LS, Furmanczyk K, Haerens P, Matias A, Perini L, Taborda R, Terefenko P, Trifonova E, Trouw K, Valchev N, Van Dongeren A, Van Koningsveld M, Williams JJ (2009) Coastal storm risk assessment in Europe: Examples from 9 study sites. J Coast Res SI 56:1632-1636.

Florek W, Kaczmarzyk J, Majewski M, Olszak IJ (2008) Lithological and extreme event control of changes in cliff morphology in the Ustka region. Landform Analysis 7:53-68

Furmańczyk KK, Dudzińska-Nowak J, Furmańczyk KA, PaplińskaSwerpel B, Brzezowska N (2011) Dune erosion as a result of the significant storms at the western Polish coast (Dziwnow Spit example). J Coast Res SI 64:756-759

Gurova ES (2004) Morphology and dynamics of the Kaliningrad region sea beaches. (in Russian). In: Orlenok VV (ed) Coastline: Morphodynamics and Geoecology, Kaliningrad State University, Kaliningrad, Russia, p 85-86
Gurwell B (2008) Coastal protection along the Baltic Sea coast Mecklemburg-Vorpommern. Die Küste. Arch Res Technol North Sea and Baltic coast 74:179-188

Hanson H (2002) Eurosion case study Ystad, Sweden, EUROSION Study. p 1-14

Harff J, Meyer M (2007) Changing Holocene coastal zones of the Baltic Sea - a modelling approach. In: Harff J, Lüth F (eds), SINCOSSinking coasts. Geosphere, Ecosphere and Anthroposphere of the Holocene Southern Baltic Sea, Bericht der Römisch-Germanischen Kommission 88, p 239-266

Hellemaa P, Doody P (1991) Finland dunes. In: Doody P (ed), Sand Dune Inventory of Europe, p15-17

Hoffmann G, Lampe R (2007) Sediment budget calculation to estimate Holocene coastal changes on the southwest Baltic Sea (Germany). Mar Geol 243:143-156

Hofstede J (2008) Coastal flood defence and coastal protection along the Baltic Sea coast of Schleswig-Holstein. Die Küste. Arch Res Technol North Sea and Baltic coast 74:170-178

Jarmalavičius D, Satkūnas J, Žilinskas G, Pupienis D (2012) Dynamics of beaches of the Lithuanian coast (the Baltic Sea) for the period 1993-2008 based on morphometric indicators. Environ Earth Sci 65:1727-1736

Jevrejeva S, Drabkin V, Kostjukov J, Lebedev AA, Leppäranta M, Mironov YeU, Schmelzer N, Sztobryn M (2004) Baltic Sea ice seasons in the twentieth century. Clim Res 25:217-227

Kelpšaitė 1, Dailidienè I (2011) Influence of wind wave climate change to the coastal processes in the eastern part of the Baltic Proper. J Coast Res SI 64:220-224

Kobelyanskaya J, Piekarek- Jankowska H, Boldyrev VL, Bobykina VP, Stępniewski P (2009) The morphodynamics of the Vistula Spit seaward coast (southern Baltic, Poland, Russia). In: Oceanological and Hydrobiological Studies, vol XXXVIII, p 41-56

Koltsova T, Belakova J (2009) Storm Surges on the Southern Coast of Gulf of Riga: Case Study of the Lielupe River. Threats to Global Water Security. NATO Science for Peace and Security Series C p $91-97$

Kont A, Ratas U, Puurmann E (1997) Sea-level rise impact on coastal areas of Estonia. Climate Change 36:175-184

Kont A, Endjärv E, Jaagus J, Lode E, Orviku K, Ratas U, Rivis R, Suursaar Ü, Tõnisson H (2007) Impact of climate change on Estonian coastal and inland wetlands - a summary with new results. Boreal Environ Res 12:653-671

Kont A, Jaagus J, Aunap R, Ratas U, Rivis R (2008) Implications of sea-level rise for Estonia. J Coast Res 24:423-431

Kortekaas S, Bagdanaviciute I, Gyssels P, Huerta JMA, Héquette A (2010) Assessment of the effects of marine aggregate extraction on the coastline: an example from the German Baltic Sea coast. J Coast Res 51:205-214

Kostrzewski A, Zwoliński Z (1995) Present-day morphodynamics of the cliff coasts of Wolin Island. J Coast Res SI 22:293-303

Kowalewska-Kalkowska H, Kowalewski M (2005) Operational hydrodynamic model for forecasting extreme hydrographic events in the Oder Estuary. Nord Hydrol 36:411-422

Kurennoy D, Ryabchuk T (2011) Wind wave conditions in Neva Bay. J Coast Res SI 64:1438-1442

Łabuz TA (2005) Dune shores of Polish Baltic coast (in Polish). Czasopismo Geograficzne 76:19-47

Łabuz TA (2009a) Distal washover fans on Świna Gate Sandbar. In: Oceanological and Hydrobiological Studies Vol. XXXVIII, p 79-95

Łabuz TA (2009b) The West Pomerania coastal dunes - alert state of their development. Z Dt Ges Geowiss 160:113-122

Łabuz TA (2012) Coastal response to climatic changes: Discussion with emphasis on southern Baltic Sea. Landform Analysis 21:43-55 
Łabuz TA (2014) Erosion and its rate on an accumulative Polish dune coast: the effects of the January 2012 storm surge. Oceanologia 56:307-326

Łabuz TA, Kowalewska-Kalkowska H (2010) Coastal abrasion of the Swina Gate Sandbar (Pomeranian Bay coast) caused by the heavy storm surge on 15 October 2009. In: Abstracts of the Storm Surges Congress 2010, 13-17 September 2010, University of Hamburg, Germany, p 115

Łabuz TA, Kowalewska-Kalkowska H (2011) Coastal erosion caused by the heavy storm surge of November 2004 in the southern Baltic Sea. Clim Res 48:93-101

Lampe R (1996) Küsten und Küstenschutz in Mecklenburg Vorpommern. Erdkundeunterricht 9:364-372

Lampe R, Janke W (2002) Salt meadow evolution and Holocene sealevel rise-the examples Kooser Wiesen and Ribnitzer Wiesen. Greifswalder Geographische Arbeiten D 27:187-198

Milerienè R, Gulbinskas S, Blazauskas N, Dailidiene I (2008) Geological indicators for integrated coastal zone management. In: US/EU-Baltic International Symposium, 27-28 May 2008, Tallinn, Estonia, p 1-4

Musielak S, Labuz TA, Wochna S (2004) Morphodynamics of sandy beaches in Pomeranian Bay (western coast of Poland) (in Russian). In: Orlenok VV (ed) Coastline: Morphodynamics and Geoecology, Kaliningrad State University, Kaliningrad, Russia, p 53-54

Musielak S, Łabuz TA, Wochna S (2007) The morphodynamics processes of coastal zone on the Dziwnow Sandbar (in Polish). Geologia i geomorfologia pobrzeża i południowego Bałtyku 7: 63-75

Orviku K, Jaagus J, Kont A, Ratas U, Rivis R (2003) Increasing activity of coastal processes associated with climate change in Estonia. J Coast Res 19:364-375

Povilanskas R (2002a) Eurosion in Gulf of Riga, Latvia, EUROSION Study, EUCC Baltic Office. pp1-17 http://copranet.projects.euccd. de/files/000136_EUROSION_Gulf_of_Riga.pdf. Accessed 10 January 2012

Povilanskas R (2002b) Case study: Klaipeda, EUROSION Study, EUCC Baltic Office, p1-19 http://databases.eucc-d.de/files/000137_ eurosion_klaipeda.pdf. Accessed 10 January 2012

Prior D (1977) Coastal mudslide morphology and processes on Eocene clays in Denmark. Geografisk Tidsskrift 76:14-33

Pruszak Z, Zawadzka E (2005) Vulnerability of Poland's coast to sealevel rise. Coast Eng J 47:131-155

Pruszak Z, Zawadzka E (2008) Potential implications of sea level rise for Poland. J Coast Res 24:410-422

Räämet A, Soomere T (2011) Spatial variations in the wave climate change in the Baltic Sea. J Coast Res SI 64:240-244

Ratas U, Rivis R, Käärt K (2008) Changes of coastal dune landscapes in Estonia. Forestry Studies 49:59-70

Ratas U, Rivis R, Truus L, Vilumaa K, Multer L, Anderson A (2011) The aeolian coastal ecosystems of Estonia and their changes. J Coast Res SI 64:430-433

Richter A, Dietrich R, Liebsch G (2007) Sea-level changes and crustal deformations at the southern Baltic Sea. In: Harff J, Lüth F (eds), Geosphere, Ecosphere and Anthroposphere of the Holocene Southern Baltic Sea, Bericht der Römisch-Germanischen Kommission $88, \mathrm{p} 81-100$

Rotnicki K, Borówka RK (1990) Impact of a future sea level rise in the Polish Baltic coastal zone. In: Titus JG, Wedge R, Psuty N, Fanscher J (eds), Changing Climate and the Coast. Washington DC p 247-264

Ryabchuk D, Sukhacheva L, Spiridonov M, Zhamoida V, Kurennoy D (2009) Coastal processes in the eastern Gulf of Finland - Possible driving forces and the connection with nearshore development. Est $\mathbf{J}$ Eng 15:151-167
Ryabchuk D, Kolesov A, Chubarenko B, Spiridonov M, Kurennoy D, Soomere T (2011) Coastal erosion processes in the eastern Gulf of Finland and their links with long-term geological and hydrometeorological factors. Boreal Environ Res 16:117-137

Schumacher W (2002) Coastal dynamics and coastal protection of the Island of Usedom. Greifswalder Geographische Arbeiten C 27 C 8 Greifswald p 131-134

Schwartz ML, Granö O, Pyökäri M (1989) Spits and tombolos in the southwest archipelago of Finland. J Coast Res 5:443-451

Schwarzer K, Diesing M, Larson M, Niedermeyer RO, Schumacher W, Furmańczyk K (2003) Coastline evolution at different time scales examples from the Pomeranian Bight, southern Baltic Sea. Mar Geol 194:79-101

Shishkina A (2010) Geological and geomorphological conditions of the coast of The Sambian Peninsula. Proceedings of the International Conference on Dynamics of Coastal Zone of Non-tidal Seas, 26-30 June 2010, Baltiysk (Kaliningrad Oblast, Russia), p 96-99

Siegel H, Seifert T, Gerth M, Ohde T, Reissmann J, Scherniewski G (2004) Dynamical processes along the German Baltic Sea coast systematized to support coastal monitoring. In: Schernewski G, Löser N (eds), Managing the Baltic Sea. Coastline Reports 2, EUCC - The Coastal Union, Warnemunde, p 219-234

Soomere T, Viška M, Lapinskis J, Räämet A (2011) Linking wave loads with the intensity of erosion along the coasts of Latvia. Est J Eng 17:359-374

Sorensen C, Munk-Nielsen CC, Piontkowitz T (2009) Storm surges in Denmark: past experiences and expectations for the future. In: Abstracts of the Storm Surges Congress 2010, 13-17 September 2010, University of Hamburg, Germany, p 1-73

Sterr H (2008) Assessment of vulnerability and adaptation to sea level rise for coastal zone of Germany. J Coast Res 24:380-393

Subotowicz W (1982) Lithodynamics of cliff coast in Poland Ossolineum, Gdańsk

Suursaar Ü, Kullas T, Otsmann M, Kõuts T (2003) Extreme sea level events in the coastal waters of western Estonia. J Sea Res 49:295-303

Suursaar Ü, Jaagus J, Kont A, Rivis R, Tönisson H (2008) Field observations on hydrodynamics and coastal geomorphic processes of Harilaid Peninsula (Baltic Sea) in winter and spring 2006-2007. Estuar Coast Shelf Sci 80:31-41

Tõnisson H, Orviku K, Jaagus J, Suursaar Ü, Kont A, Rivis R, Ratas U (2006) Coastal damages in Estonia caused by Cyclone Gudrun. In: Tubilewicz A, (ed), Coastal Dynamics, Geomorphology and Protection, p 18-26

Tõnisson H, Orviku K, Jaagus J, Suursaar Ü, Kont A, Rivis R (2008) Coastal damages on Saaremaa Island, Estonia, caused by the extreme storm and flooding on January 9, 2005. J Coast Res 24:602-614

Trenhaile AS (1997) Coastal Dynamics and Landforms, Clarendon Press, Oxford

Vallner A, Sildvee H, Torim A (1988) Recent crustal movements in Estonia. J Geodynam 9:215-223

van der Meulen F, Witter JV, Ritchie W (eds) (1991) Impact of climatic change on coastal dune landscapes of Europe. Landsc Ecol 6:1-113

Vestergaard P (1991) Morphology and vegetation of a dune system in SE Denmark in relation to climate change and sea-level rise. Landsc Ecol 6:77-87

Vestergaard P (1997) Possible impact of sea-level rise on some habitat types at the Baltic coast of Denmark. J Coast Conservat 3:103-112

Viles HA, Goudie AS (2003) Interannual decadal and multidecadal scale climatic variability and geomorphology. Earth Sci Rev 61:105-131

Visakavičius E, Kelpšaitė L, Gulbinskas S (2010) What cause Palanga coast erosion during September-October 2009? In: Abstracts of the XXIII International Conference on Coastal Evolution Studies: Traditions and Modern Concepts. Saint-Petersburg, Russia 
Volkova II, Shaplygina TV, Rezniechenko NV (2004) Estimation of sensitivity of the Vistula spit natural complexes (in Russian). In: Orlenok VV (ed) Coastline: Morphodynamics and Geoecology, Kaliningrad State University, Kaliningrad, Russia, p 215-217

Wahle M, Obst K (2009) On the move: The steep cliff coast of Jasmund (Rügen Island) In: Abstracts of the International Conference on Climate Change: The Environmental and Socio-economic Response in the Southern Baltic Region, 25-28 May 2009, Szczecin, Poland, p 135

Zawadzka-Kahlau E (1999) The development tendencies of the Southern Polish Baltic coast, (in Polish with English summary). IBW PAN, Gdańsk
Zeidler RB, Wróblewski A, Miętus M, Dziadziuszko Z, Cyberski J (1995) Wind, wave and storm surge regime at the Polish Baltic coast. J Coast Res SI 22:33-55

Zhang K, Douglas BC, Leatherman SP (2004) Global warming and coastal erosion. Climatic Change 64:41-58

Žilinskas G (2005) Trends in dynamic processes along the Lithuanian Baltic coast. Acta Zool Lit 15:204-207

Žilinskas G, Jarmalavičius D, Pupienis D (2006) Management of the Lithuanian coast of the Baltic Sea. Presentation. www.astra-project. org/sites/download/12_coastal_management.pdf 